\title{
Food crisis spurs research spending
}

More than 20 United Nations development agencies joined the World Bank and the World Trade Organization this week in Bern, Switzerland, to discuss emergency humanitarian aid and other measures to combat the growing world food crisis. The World Food Programme says it needs an extra US\$755 million just to meet existing needs for food aid.

The acute crisis is mainly due to market causes, but it is throwing the spotlight on the underlying problem of chronic underinvestment in agricultural research, experts say.

It's a wake-up call, says Nienke Beintema, who heads the Agricultural Science \& Technology Indicators (ASTI) initiative at the International Food Policy Research Institute in Wageningen in the Netherlands. "Agricultural research had fallen off the international agenda," she says. "The food crisis has brought into focus the need for agriculture for economic development - and that people need food.

"It is now back on the agenda, and hopefully will translate into more investment in agricultural research," she says. There are already signs that this may be the case. For example, last week the United Kingdom announced an $\$ 800$ million, five-year package for agricultural research in developing countries.

Such funding is badly needed, according to the International Assessment of Agricultural Knowledge, Science and Technology for Development (IAASTD), a four-year, \$10-million project with a structure of some 400 experts, akin to the Intergovernmental Panel on Climate Change. In September it is due to deliver its final assessment on how science, together with farming and economic practices, can best help to feed the poor in developing countries. But a draft version of its report warns that investment in agricultural research and its application to farming in poor countries is decreasing "at a time when it is most needed".

Overall, public spending on research such as pest and disease control and high-yielding crop varieties is growing in developing countries. However, this growth is largely accounted for by just four countries: China, India, Brazil and South Africa, according to the report. In many other developing countries, home to hundreds of millions of people, the report finds that spending is "stagnating or slipping".

That trend is all the more worrying because developing countries are benefiting less and less from transfer

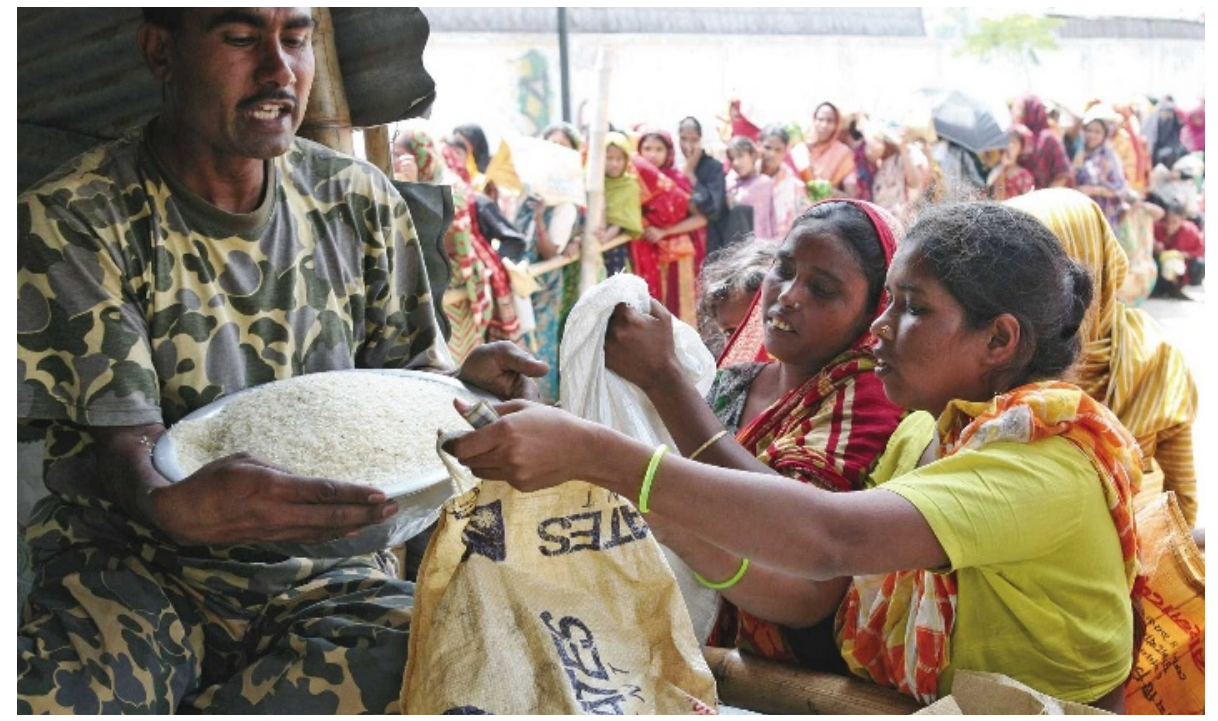

Emergency aid helps now, but agencies are looking at longer-term strategies to alleviate food shortages.

of the results of intensive agricultural research carried out by rich countries, says Frances Kimmins, a lead author of the IAASTD report. The rate of growth in investment in agricultural research by industrialized countries ground to a halt following rapid growth from the 1960s to the early 1980s after decades of food surpluses. And focus has shifted away from improving crop varieties towards food processing and other 'added-value' products, which are less relevant to farmers in developing countries.

In developed countries, most agricultural research is increasingly done by the private sector, which will not invest in crops and practices for which there are small or nonexistent markets, and where patents prevent the spread of technologies. Taken together, these trends represent a drying-up of past sources of technology transfer from wealthy to developing countries, and make a case for renewed public investment in developed nations, says Kimmins, who is also an agricultural expert at the UK-based development consultancy NR International.

With research spending high in China, India, Brazil and South Africa, these countries may take up the technology transfer gap left by rich countries, but it is too soon to tell. "Cooperation between these countries and the rest of the developing world is limited - it's only starting up," says Beintema. But the potential is there, she says, because they often share common agricultural climate zones.

Beintema's ASTI initiative is involved in a project with the Bill \& Melinda Gates Foundation to explore the potential for greater agricultural research collaborations between developing nations. One of the first issues they will tackle is getting better data to guide science policy. "I've been surprised by how poor the data are," says Beintema, who is another lead author of the IAASTD report. She points out that the most recent statistics on agricultural research date from 2000 and are full of holes - and that included data for developed countries. A priority for the project with the Gates Foundation will be to get a better grasp of technology transfer and other issues by reinforcing the capacity of developing countries to collect the data needed, she says.

Declan Butler

See Editorial, page 1. 